Türkiye Jeoloji Bülteni
Geological Bulletin of Turkey
$64(2021) 129-142$
doi: $10.25288 /$ tjb.731580

\title{
Geochemical and Petrological Studies of Permo-Carboniferous Sandstones from the Rangit Pebble-Slate Formation, Sikkim Lesser Himalaya, India: Implication for Provenance, Tectonic Setting, and Paleoclimate
}

\author{
Raj Kumar Priya $^{1^{*}} \mathbb{D}$, Vinod Chandra Tewari ${ }^{1} \mathbb{D}$, Rakesh Kumar Ranjan ${ }^{1} \mathbb{D}$ \\ ${ }^{1}$ Department of Geology, Sikkim University, Gangtok, Sikkim, India 737102
• Geliş/Received: 03.05.2020 • • Düzeltilmiş Metin Geliş/Revised Manuscript Received: 15.09.2020 • Kabul/Accepted: 16.09.2020 • Çevrimiçi Yayın/Available online: 08.12.2020 • Baski/Printed: 15.01.2021 \\ Araştırma Makalesi/Research Article Türkiye Jeol. Bül./Geol. Bull. Turkey
}

\begin{abstract}
The Permo-Carboniferous depositional sequence of Lower Gondwana in Sikkim Lesser Himalaya was investigated through an integrated approach of lithological, petrological, and geochemical studies. Lithologically, it is characterized by glacial diamictite at the base and shale-sandstone facies at the top of a sequence which is interpreted as a glaciomarine deposit. Coarser sandstone and massive diamictite composed of quartz, feldspar, muscovite, zircon, and other lithic fragments are observed in thin section. Geochemistry of all studied samples from the Rangit Pebble Slate Formation shows the dominance of silicon dioxide compared to other elemental oxides. The tectonic discrimination diagram positively infers passive margin sedimentation from a felsic-rich provenance. Chemical Index of Alteration was used to depict the weathering trends of all studied samples which reflect paleosedimentation under humid to sub-humid climatic conditions.
\end{abstract}

Keywords: Gondwana, Geochemistry, Paleoclimate, Rangit Pebble Slate Formation, Sikkim Lesser Himalaya.

\section{INTRODUCTION}

Permo-Carboniferous Gondwana sequences of Peninsular India have been well studied and categorized mainly into three major basins, i.e. Son-Mahanadi basin, Pranhita-Godavari basin and Damodar basin. Simultaneously, equivalent sedimentary sequences from the PermoCarboniferous were also deposited around the periphery as peri-Gondwana sequences which are well preserved and exposed in Extra-Peninsular India, i.e. Kashmir, Sikkim and Arunachal Pradesh. The Rangit Pebble Slate (RPS) Formation occurs in the Lesser Himalaya of Sikkim in the zone of the Rangit window. Rangit Pebble Slate Formation is considered to be Upper Carboniferous to Lower Permian in age on the basis of similar lithofacies and fossil correlations with the peninsular
Gondwana basin in India (Priya et al., 2019). The presence of marine fossils like Eurydesma and glacial diamictite with large boulders and dropstones embedded in the coarser sandstone clearly indicates the influence of glaciomarine environments (Acharyya and Ray, 1977; Raichaudhari, 2002; Priya et al., 2019). Despite having global significance, this area has not been well studied due to poor exposure of its outcrop in hilly terrain. This is our first attempt to unravel the geological history of Rangit Pebble Slate Formation through the combined approaches of lithostratigraphy, petrography, and geochemistry. Additionally, we also documented the detailed lithofacies description of this Formation. The Rangit Pebble Slate Formation unconformably overlies the Proterozoic Buxa Formation (Gupta and Roy, 1981; Roy, 1973; Priya et al., 2019). The 
strata of the RPS Formation are scanty, folded and metamorphosed in some places and it was always considered to be equivalent to the Talchir Formation of Peninsular India. Many significant lithological features like diamictite, pebble- slate and coarser-medium sandstone facies with marine fossils occur at the base of the RPS Formation which suggests the influence of glaciomarine environment during sedimentation (Raichaudhari, 2002; Priya et al., 2019). The alternate beds of fine sandstone and olive-green shale at the top of the sequence indicate shallow marine transgressional deposition (Priya et al., 2019). The combined approach of both petrological and geochemical studies helped to effectively understand the tectonic setting, provenance history, weathering trends and paleoclimatic conditions of sediment deposition.

\section{METHODS AND MATERIALS}

Samples of sandstone and massive diamictite were collected from the study area for petrographic and geochemical study. Modal analysis of sandstone samples were completed with a Leica microscope (Leica DM-2700P) by using point counting methods to determine the quantitative mineralogical aspects. Geochemical analyses including major elements in sandstone samples were analyzed at Birbal Sahni Institute of Palaeosciences (BSIP), Lucknow, India. Major oxides (i.e. $\mathrm{SiO}_{2}, \mathrm{Al}_{2} \mathrm{O}_{3}, \mathrm{Fe}_{2} \mathrm{O}_{3}, \mathrm{TiO}_{2}, \mathrm{MnO}, \mathrm{MgO}$, $\mathrm{CaO}, \mathrm{Na}_{2} \mathrm{O}, \mathrm{K}_{2} \mathrm{O}, \mathrm{P}_{2} \mathrm{O}_{5}$ ) were detected by X-Ray Fluorescence (PANalytical, Axios).

All the standard procedures were followed for sample preparation (Takahashi, 2015). The loss on ignition (LOI) was calculated by weight difference after ignition at $1000{ }^{\circ} \mathrm{C}$. We studied the texture and major composition of sandstones using thin sections with optical microscopy while normalized major element oxides were used for the interpretation of tectonic setting, provenance, and paleoenvironment of sedimentation. The Chemical Index of Alteration (CIA) was also used as a tool for paleoclimatic reconstruction on the basis of chemical weathering.
GEOLOGICAL SETTING OF THE STUDY AREA

The present study area falls within the Rangit window zone in the Sikkim Lesser Himalaya which is comprised of mainly two lithostructural units, i.e. Daling and Gondwana Group (Ray and Neogi, 2011; GSI, 2012), given in Table 1. The Rangit Pebble Slate Formation stratigraphically belongs to the Lower Gondwana group and is considered equivalent to the Talchir Formation of Peninsular India. Gondwana group of rocks are only exposed within the Rangit window of Sikkim Lesser Himalaya, while the Daling group rocks are exposed within and outside the Rangit window (Figure 1).

\section{Daling Group}

The Daling Group can be classified into three major Formations viz. Gorubathan, Reyong, and Buxa Formations. The Gorubathan Formation consists of green slate, phyllite, and fine-grained cherty quartzite, while the Reyong Formation consists of quartzites, variegated slates, and phyllites. It also incorporates persistent bands of carbonates (GSI, 2012). The Buxa Formation occurs below the horizon of the Rangit Pebble Slate Formation as discontinuous patches and is well exposed near Tatopani and Mamley areas in South Sikkim. It is essentially comprised of dolostone, cherty quartzite, limestone, and variegated slate. Dolostone is characterized by the presence of laminated to massive grey to pink beds and stromatolites, filamentous and coccoidal cyanobacterial microfossils and algal mat facies which were assigned Lower to Middle Riphean (Neoproterozoic) age by previous workers (Ray, 1976; Acharyya, 1971; Tewari, 2011). Ray and Neogi (2011) mapped a new Formation, i.e. Phong La Formation around the Rangit window (RW) which is siliciclastic in composition and was assigned to the Buxa Formation (Figure 1). 
Table 1. General stratigraphic sequence of Sikkim Lesser Himalaya (after Acharyya and Ray, 1977; GSI, 2012; Priya et al., 2019)

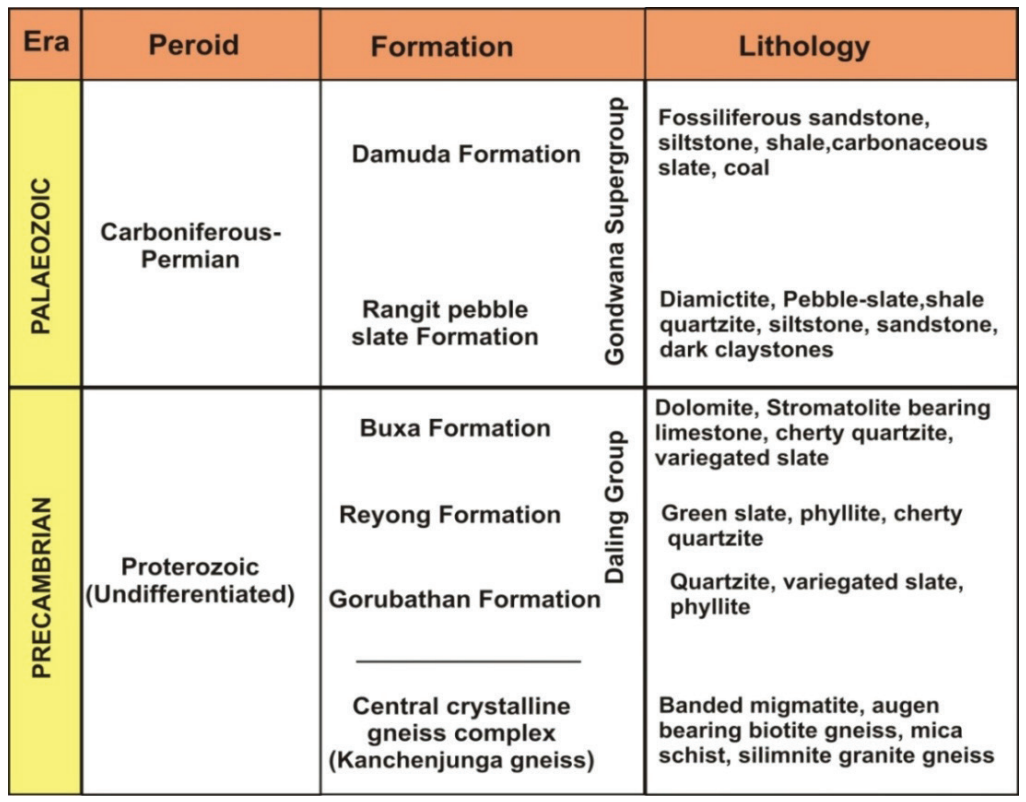

\section{Gondwana Group}

The youngest stratigraphic unit in the SikkimLesser Himalaya consists of the Lower Gondwana Group. Further, the Lower Gondwana Group is distinctly subdivided into Upper and Lower sequences. The upper sequences of Lower Gondwana are designated as Damuda Formation, while the lower sequence is represented by the Rangit Pebble Slate Formation, as given in Figure 1. The Damuda Formation is mainly composed of sandstone, shale, and coal with Gondwana plant fossils (Gupta and Roy, 1981; Roy, 1973; Priya et al., 2019). Alternate bands of sandstone, carbonaceous shale and coal are well exposed along the Rangit River on the Jorethang- Reshi road. Coal seams are exposed discontinuously in a narrow strip of variable thickness around Namchi, Reshi and Jorethang areas. Carbonaceous shale and sandstone are occasionally dominated by plant fossils like Glossopteris and Vertebraria (GSI, 2012). The Lower Gondwana sequence is distinctly recognized by the Rangit Pebble Slate Formation which comprises a diamictite unit, sandstone, shale, dark grey micaceous slate, and para conglomerate (GSI, 2012; Priya et al., 2019). The outcrops of the Rangit Pebble Slate Formation are scanty in nature and poorly exposed near Tatopani and along the Namchi-Wak-Sikkip road. The presence of Cryogenic diamictites and marine Eurydesma fauna in the lower unit of Gondwana Sikkim-Lesser Himalaya clearly indicates the influence of a glaciomarine environment during the Permo-Carboniferous Period (Acharyya and Ray, 1977; Priya et al., 2019).

\section{LITHOFACIES OF RANGIT PEBBLE- SLATE FORMATION}

Detailed lithofacies of the Rangit Pebble Slate Formation in the Lower Gondwana unit of Sikkim reveals three major facies associations, viz., diamictite-sandstone facies, sandstone-shale facies and siltstone-shale facies as shown in Figure 2a. The contacts between all three major facies are conformable. They are easily detectable and markable in outcrop sections. The massive conglomerate-sandstone facies are exposed near Tatopani and along with Namchi-Wak-Sikkip 
road. The diamictite-sandstone facies is considered one of the important marker strata for the PermoCarboniferous Lower Gondwana sequence and is equivalent to the Talchir Formation in the Indian Peninsular Gondwana (Priya et al. 2019). The massive diamictite-bearing facies are poorly sorted and composed of various sub-angular clasts of quartz, chert, dolomite and other lithic fragments with the matrix as shown in Figure $3 \mathrm{a}, \mathrm{b} \& \mathrm{c}$. We also recorded many large sized stromatolite boulders, dropstones, and pebble grains of slate, carbonate, and quartzite embedded in the consolidated diamictite beds, which infers cryogenic sedimentation as shown in Figure $3 \mathrm{a}, \mathrm{b}$ $\&$ e). Dropstones are one of the most significant sedimentary structures which indicates glacial environment of deposition in Figure $3 b$ \& e. The pebbly sandstone-siltstone-shale facies occurs just above the diamictite facies with erosional and gradational contact as shown in Figure $3 c \& d$. It is mostly composed of coarser quartz grains which are moderately to well sorted, and sub-rounded to rounded in texture. The sandstone-shale lithofacies is mainly composed of massive and horizontally-stratified sandstone with interbedded shales as shown in Figure 3e \& f. Fine sandstone is mostly arenitic in nature, while the interbedded layers of olive-green shale are slaty in nature. The alternating sequences of the above facies is designated as the Rangit Pebble Slate Formation as shown in Figure 2a. The complete lithostratigraphic unit shows upward-fining sequences.

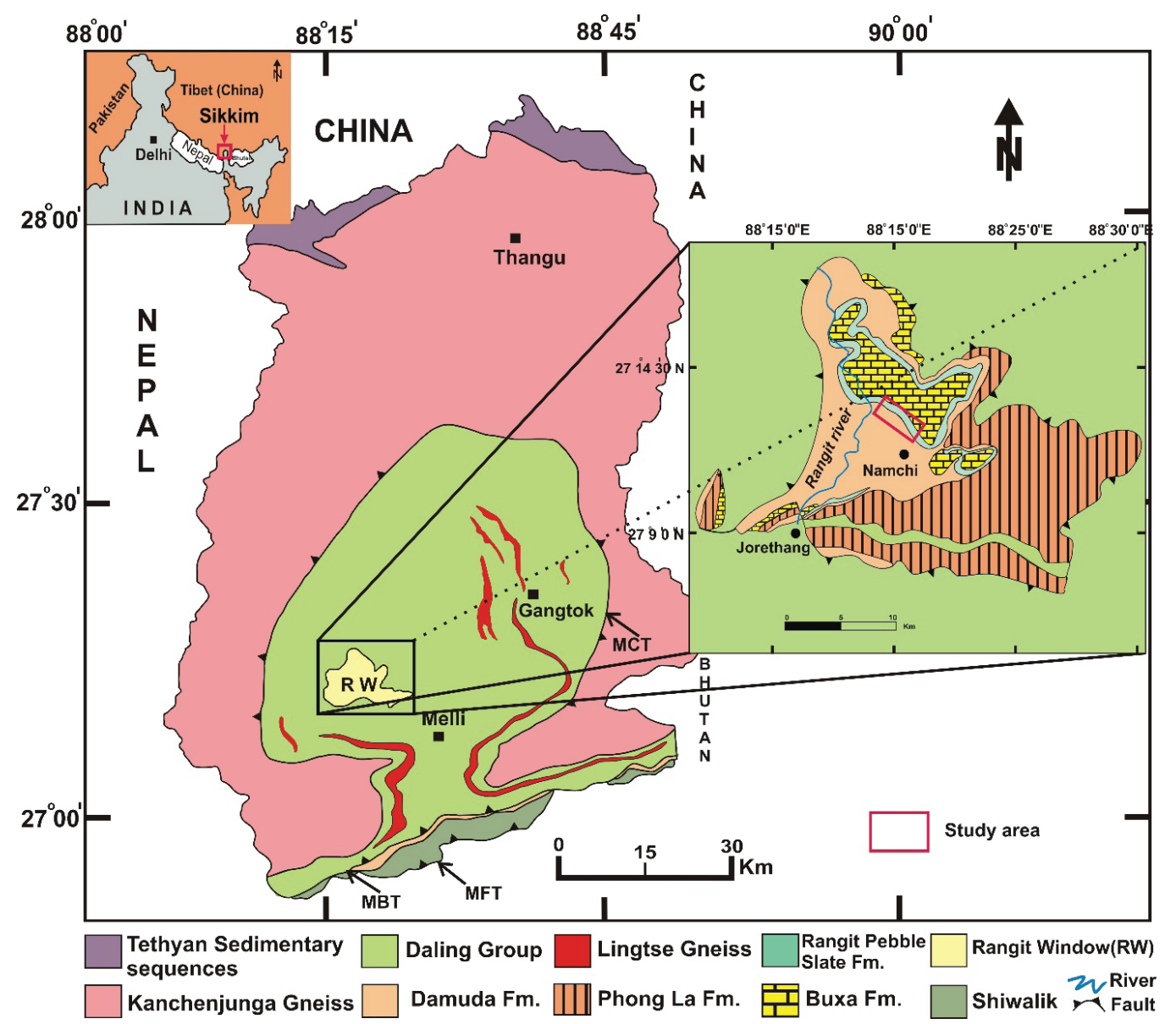

Figure 1. Geological map of Sikkim Himalaya and the study area (modified after Ray and Neogi, 2011; GSI, 2012; Chakarborty et al., 2016) 


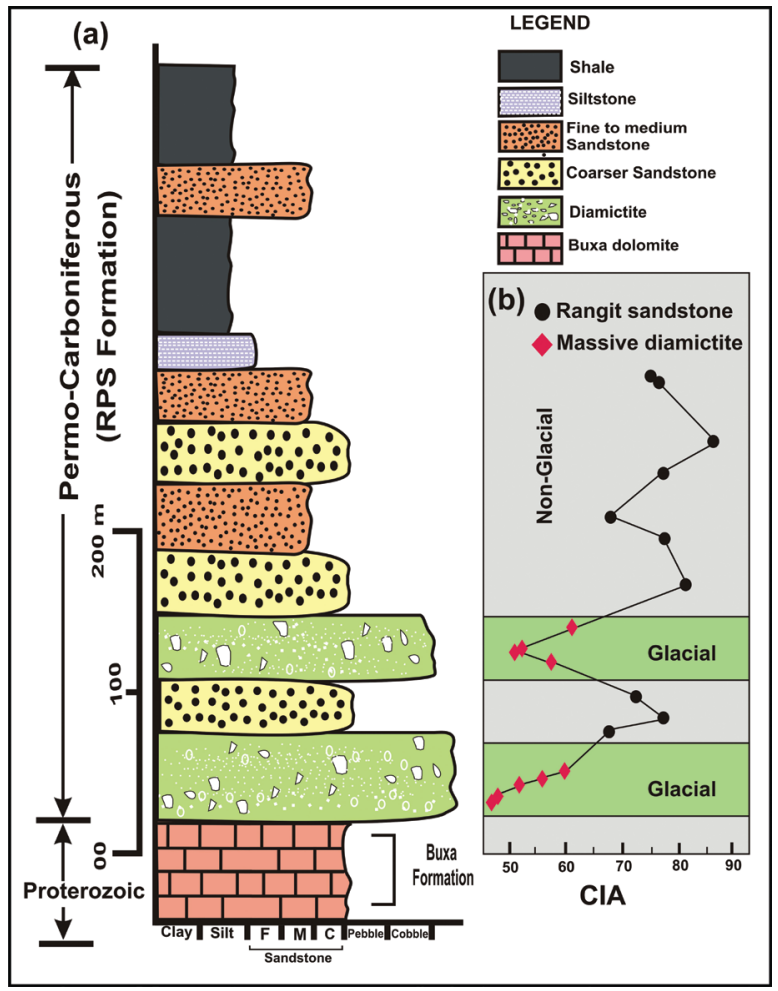

Figure 2. a) Lithostratigraphic section of the RPS Formation, Sikkim Lesser Himalaya. b) Chemical Index of Alteration (CIA) for massive diamictite (glacial) and sandstone (non-glacial).

\section{PETROGRAPHIC STUDIES}

The petrographic investigation of PermoCarboniferous sandstone and massive diamictite from Lesser Himalaya of Sikkim shows wide variation in its texture and sorting. Thin section samples of Rangit massive diamictite and sandstone were made for petrographic analysis which include mineral composition, texture and other diagenetic features. The grains were identified in each thin section by the Dickinson point counting method and normalized into QFL percentages for modal analysis (Table 2). Further, the relationships between sandstone composition and tectonic setting were depicted on the QFL ternary plot given by Dickinson and Suczek (1979) and Dickinson et al. (1983). Massive diamictite and sandstones from Rangit Pebble Slate Formation are predominantly composed of quartz grains with rounded to subrounded texture. Matrix-supported diamictite is mostly subangular to subrounded in texture. Monocrystalline quartz grains with undulose extinction, as shown in Figure $4 \mathrm{a} \& \mathrm{~b}$, are relatively more abundant $(>76 \%)$ than polycrystalline quartz in thin sections of RPS sandstone and massive diamictite. The subhedral grains of plagioclase with albite twinning and microcline as K-feldspar are prominently present in thin sections, as shown in Figure 4 a, b, c \& e. Other accessory minerals like muscovite, zircon, and lithic fragments were also observed in thin section as shown in Figure $4 b, d \& f$, which are metamorphosed to some extent perhaps due to tectonic events. Fine sandstone of the RPS Formation is mineralogically mature and belongs to arenite sandstone. On triangular diagrams with end members of quartz (Q), feldspar (F) and lithic fragments (L), samples mainly plotted into three important fields, i.e. continental block, magmatic arc, and recycled orogeny as given in Figure 5b. RPS Formation massive diamictite and coarser sandstone samples are mainly enriched with monocrystalline quartz grains, undegraded feldspar grains and lithic fragments.

Unaltered feldspar grains in massive diamictite suggest cold environment of deposition. It is evident from the QFL plot that most of the sandstone samples fall in the field of quartz arenites, while massive diamictite samples occupied the field of subarkose and sublithic arenites as shown in Figure 5a. Tectonically, it falls in the fields of continental block and recycled orogen which indicates that these sediments may have been derived from stable plutonic craton and meta-sedimentary rocks as given in Figure $5 b$. 

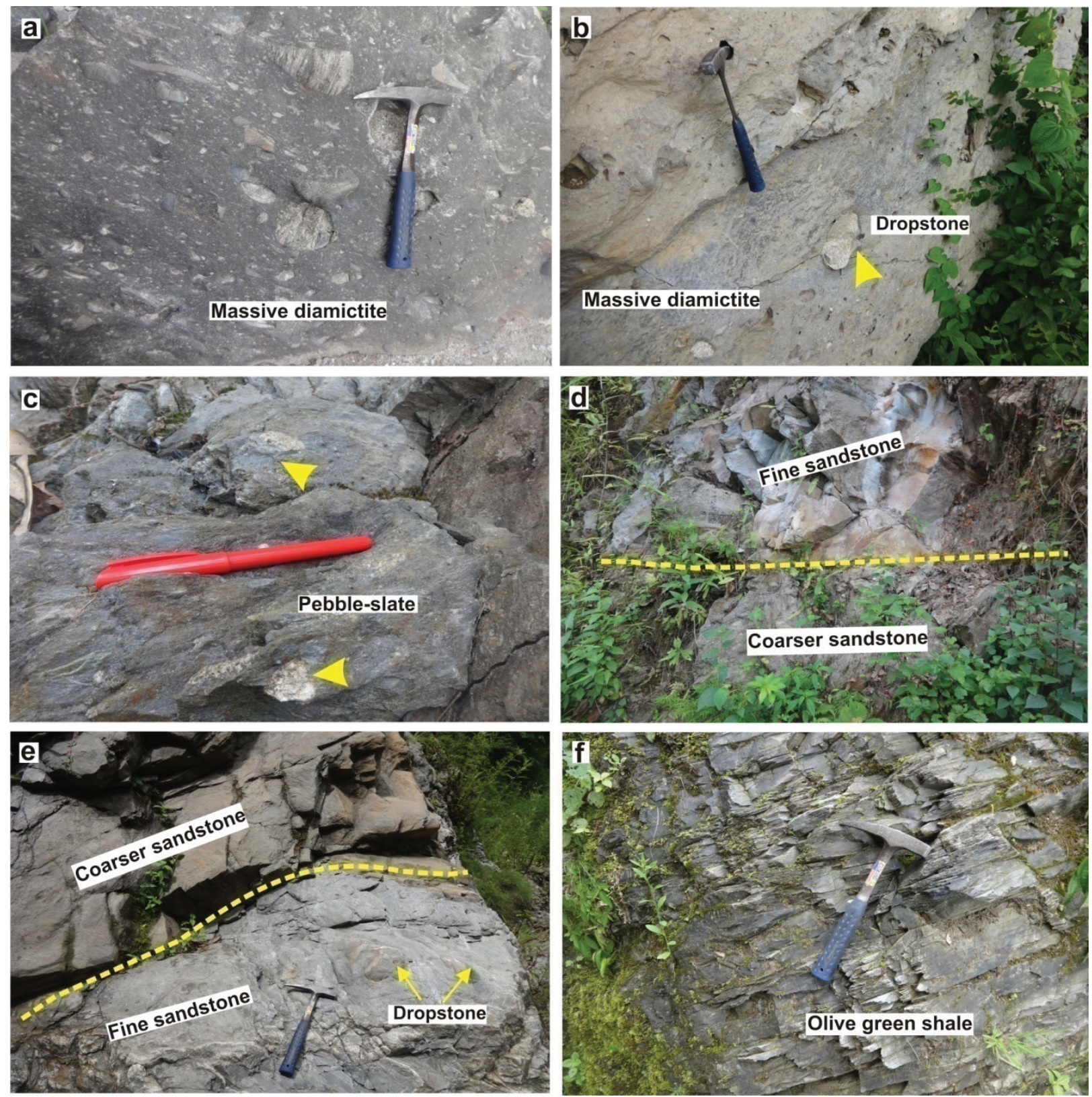

Figure 3. Field photographs of RPS Fm. stratigraphic section which depicts massive diamictite (a-c) with alternate beds of coarser-fine sandstone (d-e) and shale (f), Sikkim Lesser Himalaya, NE, India.

\section{GEOCHEMISTRY OF RANGIT PEBBLE SLATE FORMATION SANDSTONE}

The geochemical characteristics of sedimentary rock are one of the useful tools in determining the depositional setting and its associated provenance. It does not only help us to understand its whole geological history but also provides deep insight into the source of sediments, tectonic setting, and paleoclimate of sedimentation in detail. Major elements in rocks play a vital role to decipher the composition, tectonic setting and provenance of any sedimentary basin (Bhatia, 1983). 


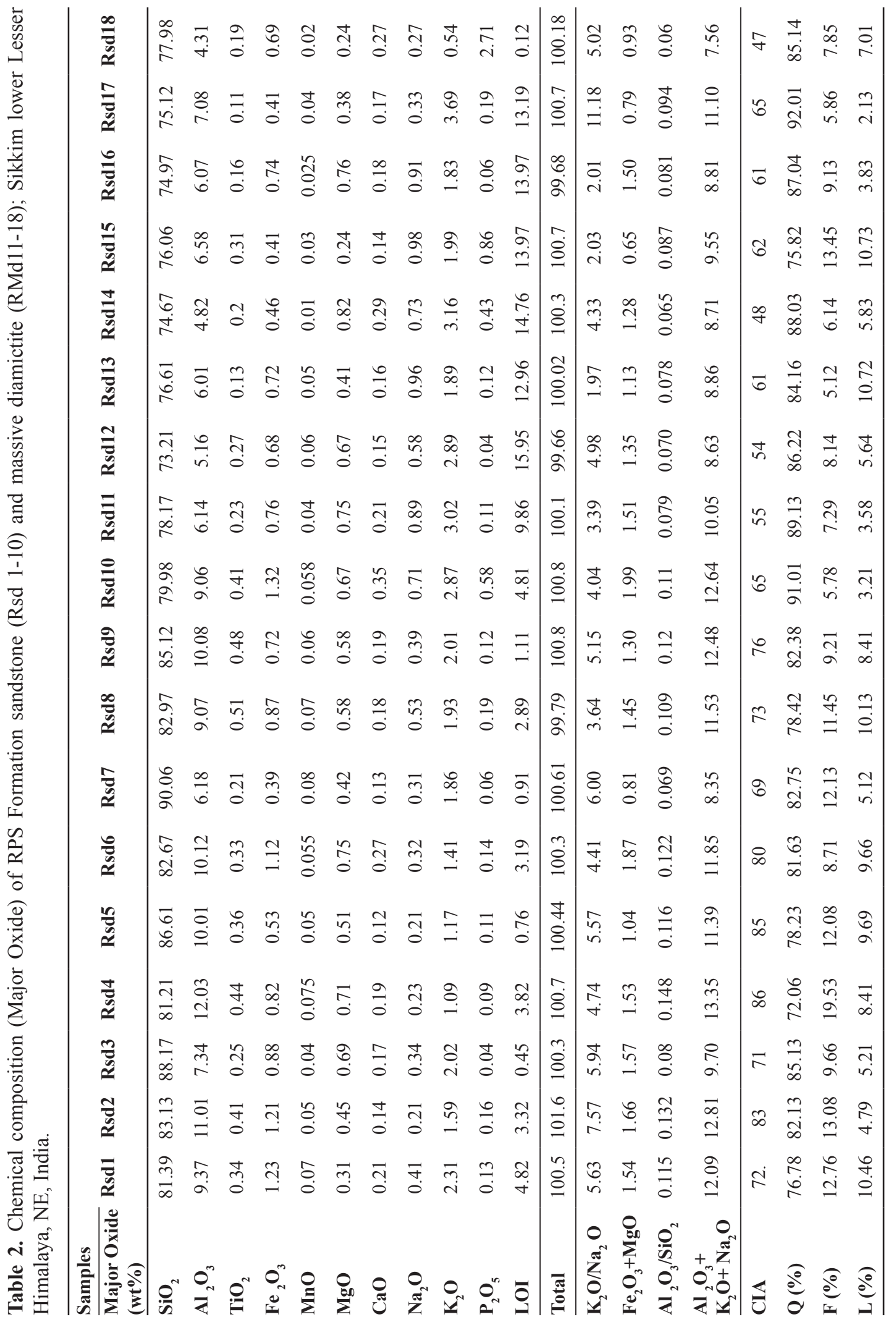



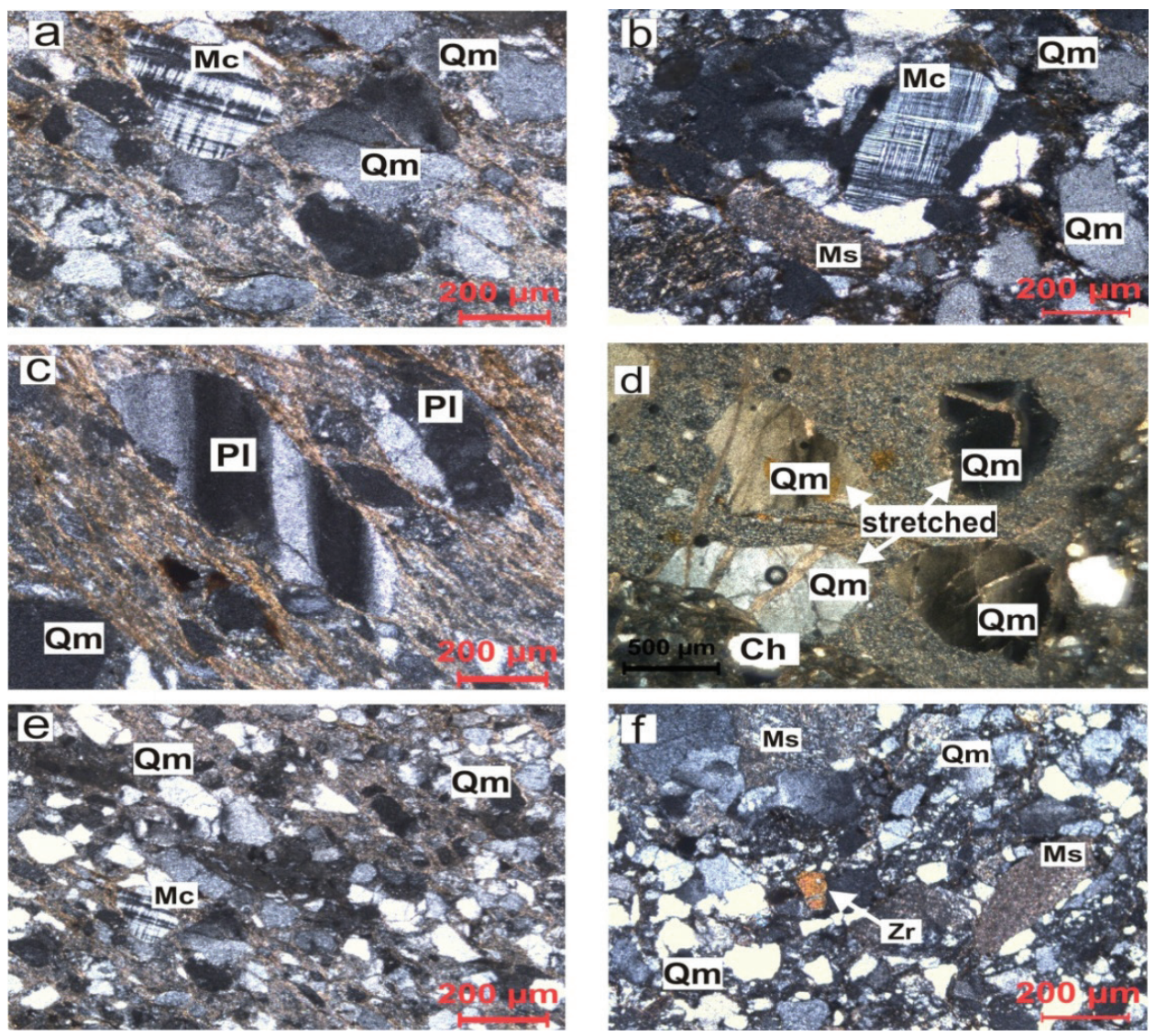

Figure 4. Photomicrograph of the RPS Fm. diamictite (a-d) and sandstone (e-f), Sikkim Lesser Himalaya. (a-d) show monocrystalline quartz grains $(\mathrm{Qm})$ with subangular to subrounded texture with sedimentary fragment such as microcline (Mc), chert $(\mathrm{Ch})$, muscovite $(\mathrm{Ms})$ and plagioclase $(\mathrm{Pl})$ embedded in a matrix. (d-e) show the dominance of quartz grains $(\mathrm{Qm})$ with the presence of muscovite $(\mathrm{Ms})$, microcline $(\mathrm{Mc})$ and zircon $(\mathrm{Zr})$ in fine-grained sandstone.
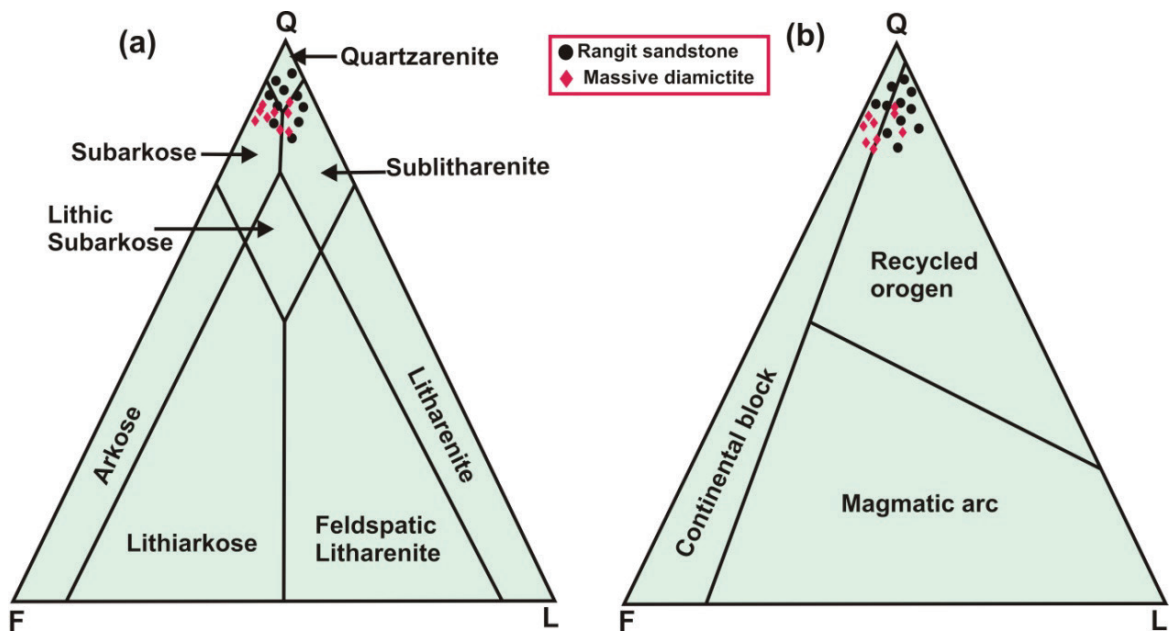

Figure 5.a) Classification of RPS Formation sandstones and massive diamictite on the basis of QFL (Q- quartz, Ffeldspar, L- lithic fragments). (b) Triangular QFL plot showing provenance fields for the RPS sandstone and massive diamictite (Dickinson and Suczek, 1979). 
Rangit Pebble Slate Formation is composed of coarser to fine sandstone in the lithostratigraphy which is enriched with quartz grains. Geochemically, all studied samples were enriched in $\mathrm{SiO}_{2}$ content, which ranges from 73.21-90.06 percent by weight (Table 2) Compositional variation in the major elemental oxides in the RPS sandstone are represented on Harker diagrams as shown in Figure 6 which basically plots major oxides against $\mathrm{SiO}_{2}$. The negative correlation between $\mathrm{SiO}_{2}$ and other major oxides (i.e. $\mathrm{CaO}$, $\mathrm{Na}_{2} \mathrm{O}, \mathrm{K}_{2} \mathrm{O}, \mathrm{Al}_{2} \mathrm{O}_{3}, \mathrm{MgO}, \mathrm{MnO}, \mathrm{TiO}_{2}$, and $\mathrm{Fe}_{2} \mathrm{O}_{3}$ ) confirms the enrichment of quartz in all samples.

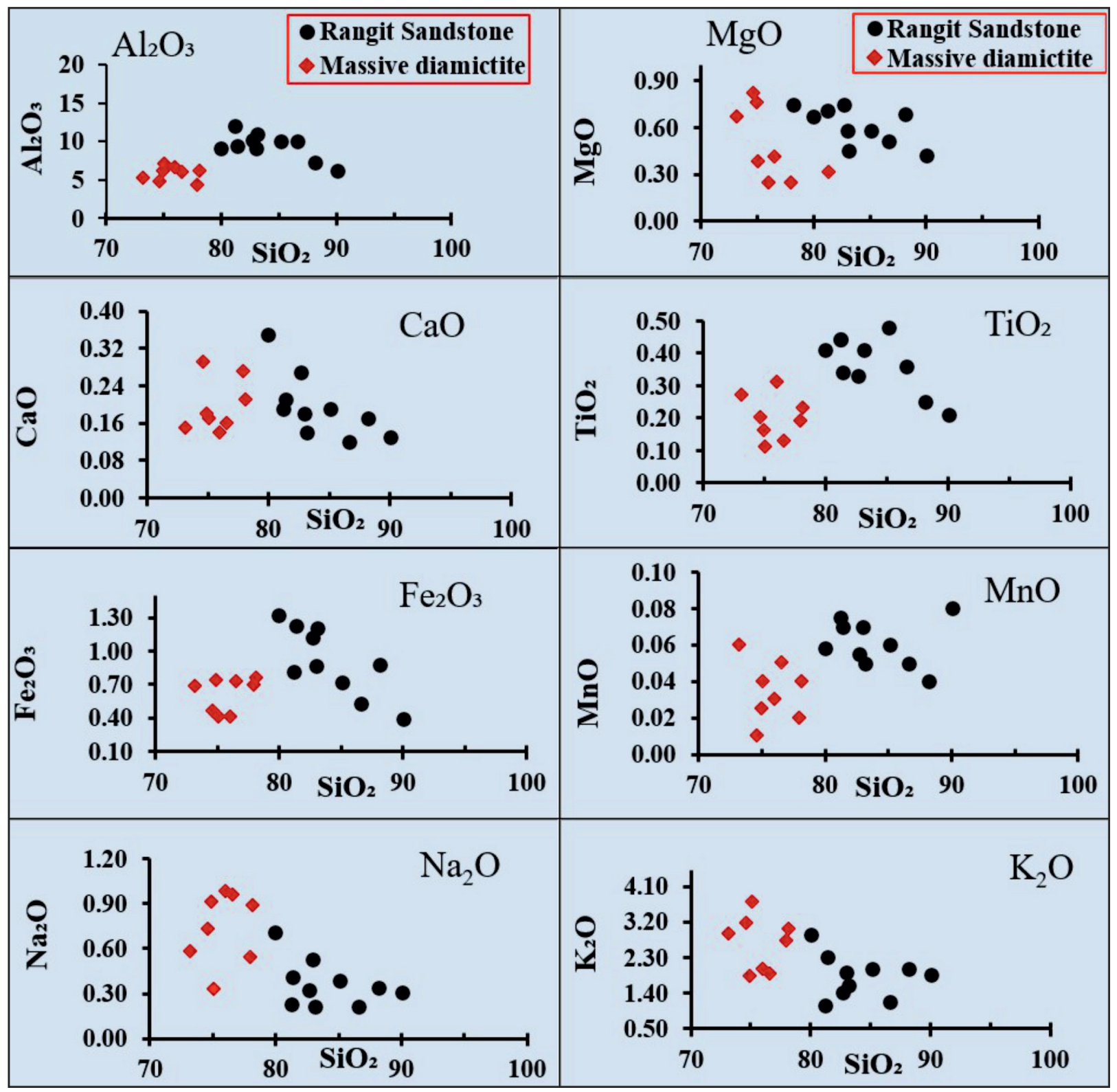

Figure 6. Binary Harker variation diagrams for RPS Formation sandstone and massive diamictite of Sikkim Lesser Himalaya, NE, India. 
It is well known that the concentration of feldspar in sedimentary rock is mainly controlled by $\mathrm{Ca}, \mathrm{Na}$ and $\mathrm{K}$ elements (Bhatia, 1983). The depletion trend of $\mathrm{K}_{2} \mathrm{O}, \mathrm{CaO}$, and $\mathrm{Na}_{2} \mathrm{O}$ infers the depletion of feldspar mineral (Crook, 1974; Bhatia, 1983; Dabard 1990). The samples from the RPS Fm. sandstone displayed strong depletion of $\mathrm{K}_{2} \mathrm{O}$ and $\mathrm{Na}_{2} \mathrm{O}$ which may be due to lower concentrations of feldspar remaining in the deposited sediment after intense weathering during transportation.

The values of $\mathrm{K}_{2} \mathrm{O}$ and $\mathrm{Na}_{2} \mathrm{O}$ in massive diamictite are relatively higher than sandstone which might be a consequence of undegraded feldspar grains in cold environment remaining unaltered in the sample, as given in Table 2. The elemental oxides of $\mathrm{Na}_{2} \mathrm{O}$ showed greater depletion relative to $\mathrm{K}_{2} \mathrm{O}$ in all samples, which implies the dominance of K-feldspar over plagioclase feldspar. The presence of aluminum silicate minerals like muscovite is significantly reflected through higher values of $\mathrm{Al}_{2} \mathrm{O}_{3}$ and $\mathrm{Fe}_{2} \mathrm{O}_{3}$ in all studied samples.

\section{PROVENANCE AND TECTONIC SETTING}

Geochemical discrimination is the most reliable and successful tool for determining provenance and tectonic setting. A number of plots have been used to describe different types of tectonic settings and provenance. For this study, plots (Bhatia and Crook, 1986; Roser and Korsch, 1986) were chosen to classify distinct tectonic setting and provenance. The plot given by Bhatia and Crook (1986) of major elemental oxides $\left(\mathrm{K}_{2} \mathrm{O}-\mathrm{Na}_{2} \mathrm{O}\right)$ was used to calculate the richness of quartz in the studied samples which indicates their derivation from quartz-rich provenance as shown in Figure 7. A geochemical model produced by Roser and Korsch (1986) were used to distinguish different tectonic areas/settings, i.e. active continental margin (ACM), oceanic island arc margin (ARC) and passive margin $(\mathrm{PM})$, which is based on $\mathrm{K}_{2} \mathrm{O} / \mathrm{Na}_{2} \mathrm{O}$ ratio and $\mathrm{SiO}_{2}$ content. The maximum number of the studied samples falls under the boundary of passive margin (PM) as shown in Figure 8. This tectonic characterization strongly suggests that all studied sediments in the RPS Formation were accumulated and deposited on a passive margin.

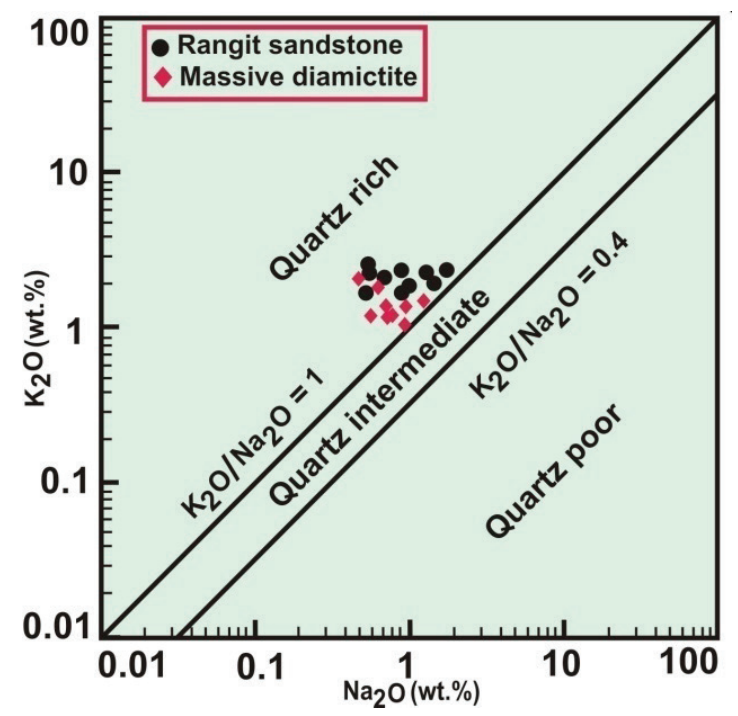

Figure 7. Plot of $\mathrm{K}_{2} \mathrm{O}-\mathrm{Na}_{2} \mathrm{O}$ to analyze the abundances of quartz in the studied samples from the RPS Fm. sandstone and massive diamictite (after Bhatia and Crook, 1986)

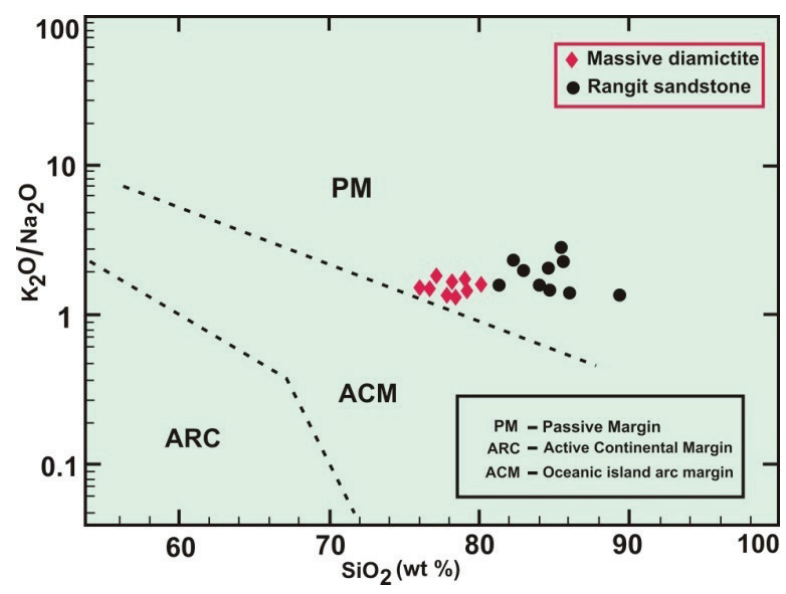

Figure 8: Plot of tectonic discrimination for RPS Fm. (Roser \& Korsch 1986).

\section{WEATHERING AND PALEOCLIMATE}

Weathering trends and paleoclimate proxies provide clues to unravel the composition and paleoclimatic conditions of the parent source 
rock and depositional environment. The Chemical Index of Alteration (CIA), A-CN-K plot and $\mathrm{SiO}_{2}$ vs. $\left(\mathrm{Al}_{2} \mathrm{O}_{3}+\mathrm{K}_{2} \mathrm{O}+\mathrm{Na}_{2} \mathrm{O}\right)$ plot were used to depict the intensity of weathering and paleoclimate environment. An equation formulated by Nesbitt and Young (1982) allows calculation of the intensity of weathering as follows: $\mathrm{CIA}=\left[\mathrm{Al}_{2} \mathrm{O}_{3} /\right.$ $\left.\left(\mathrm{Al}_{2} \mathrm{O}_{3}+\mathrm{CaO}^{*}+\mathrm{Na}_{2} \mathrm{O}+\mathrm{K}_{2} \mathrm{O}\right)\right] \mathrm{X} 100$

In the formula, the major oxides of an element $\left(\mathrm{Al}_{2} \mathrm{O}_{3} \mathrm{Na}_{2} \mathrm{O}\right.$ and $\left.\mathrm{K}_{2} \mathrm{O}\right)$ are expressed in molar proportions, while the remaining content of $\mathrm{CaO}^{*}$ is incorporated into the silicate fraction of samples (McLennan et al., 1993). The CIA value was widely applied for both glacial deposits (Condie et al., 2001; Scheffler et al., 2003; Dobrzinski et al., 2004) and non-glacial deposits (Aristizabal et al., 2005; Kahmann et al., 2008). The index value of the CIA is combined with alternate diamictite and sandstone facies to display and reconstruct the variation in the paleoclimatic conditions during sedimentation as shown in Figure 2b. The CIA value of the studied RPS Fm. Sandstone, as given in Table 2, ranges from 71 to 86 which infers low to moderate chemical weathering while the Rangit massive diamictite has values of 47 to 65 which reflects lowest chemical weathering due to cold and semi-humid conditions. Alternately, the A-CN-K $\left(\mathrm{Al}_{2} \mathrm{O}_{3}-\mathrm{CaO}^{*}+\mathrm{Na}_{2} \mathrm{O}-\mathrm{K}_{2} \mathrm{O}\right)$ triangular plot given by Nesbitt and Young (1982) was also used to demonstrate the variable intensity of chemical weathering as shown in Figure 9.

The samples of RPS Fm. diamictite plotted close to K-feldspar and illite-muscovite minerals which suggests low grade weathering due to glacial environment. Mostly sandstone samples plotted along the $\mathrm{Al}_{2} \mathrm{O}_{3}-\mathrm{CaO}^{*}(\mathrm{~A})$ and $\mathrm{Na}_{2} \mathrm{O}(\mathrm{K})$ line as shown in Figure 9, indicating the derivation of $\mathrm{K}$ and $\mathrm{Ca}$ minerals from feldspar due to progressive weathering of meta-sedimentary and granite-like source rocks. Further, a plot between elemental oxides of $\mathrm{SiO}_{2}$ and $\left(\mathrm{Al}_{2} \mathrm{O}_{3}+\mathrm{K}_{2} \mathrm{O}+\mathrm{Na}_{2} \mathrm{O}\right)$ provides a unique way to depict and discriminate paleoclimate environment of deposition (Suttner and Dutta 1986). The studied diamictite samples fall in the area of humid climatic conditions, while sandstones occupied a semi-humid area as shown in Figure 10. Therefore, CIA values and $\mathrm{SiO}_{2}$ vs $\left(\mathrm{Al}_{2} \mathrm{O}_{3}+\mathrm{K}_{2} \mathrm{O}+\mathrm{Na}_{2} \mathrm{O}\right)$ plots clearly suggest and indicate that the massive diamictite of the RPS formation were deposited in a glacial environment, whereas the upper RPS sandstone was accumulated under semi-humid conditions.

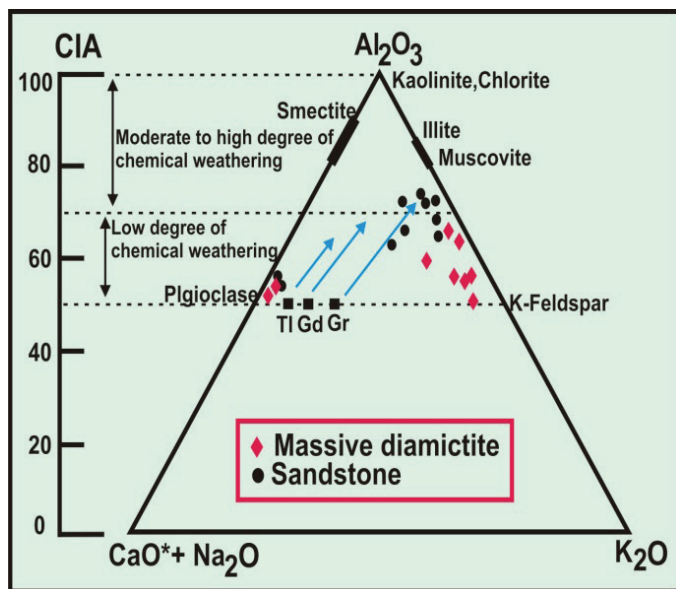

Figure 9. A-CN-K $\left(\mathrm{Al}_{2} \mathrm{O}_{3}-\mathrm{CaO} *+\mathrm{Na}_{2} \mathrm{O}-\mathrm{K}_{2} \mathrm{O}\right)$ ternary plot of Permo-Carboniferous RPS sandstone and massive diamictite associated with chemical index of alteration (CIA). Squares symbolize the average composition of granite (Gr), tonalite (Tl) and granodiorite $(\mathrm{Gd})$ with other minerals (after Nesbitt and Young, 1982)

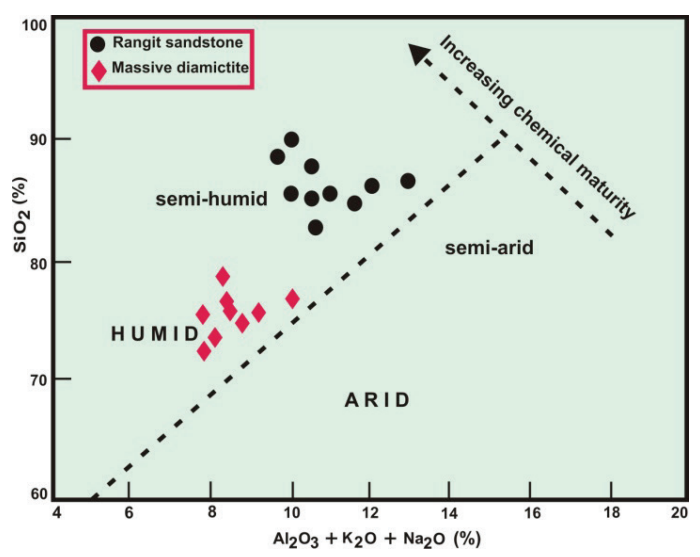

Figure 10. $\mathrm{SiO}_{2}$ versus $\left(\mathrm{Al}_{2} \mathrm{O}_{3}+\mathrm{K}_{2} \mathrm{O}+\mathrm{Na}_{2} \mathrm{O}\right)$ paleoclimate discrimination diagram of Permo-Carboniferous RPS Fm sandstones and massive diamictite from Sikkim Lesser Himalaya (after Suttner and Dutta 1986). 


\section{DISCUSSION}

The extra-peninsular Gondwana sequence of Sikkim Lesser Himalaya is considered in terms of its tectonic setting, provenance and paleoclimate study. The Gondwana sequence of Sikkim Lesser Himalaya is highly disturbed due to folding and thrusting episodes during the Himalayan Orogeny. As a result of collision of the Indian Plate and Eurasian Plate around 50 million years ago, the major tectonic events also disturbed the Sikkim Lesser Himalayan Daling and Gondwana Group of sediments exposed in the Rangit window. The integrated lithological, petrological, and geochemical approaches were used for evaluation of the Rangit Pebble Slate Formation of Sikkim Lesser Himalaya. Lithological associations of these peri-Gondwana sequences from Sikkim Lesser Himalaya include the diamictite facies at the base and the alternate sandstone-shale facies at the top of the sequence. The lowermost bed of the RPS Fm. is characteristically recognized by boulder beds and diamictite facies which suggests a glacial environment of deposition, while the upper beds of alternate sandstone and shale are considered to be the consequence of marine transgression. The undecomposed and unaltered mineral grains like quartz, feldspar, muscovite, zircon and other lithic fragments are predominantly observed in thin sections of massive diamictite, while the depletion of feldspar and enrichment of quartz grains show the mineralogical maturity of RPS Fm. sandstone in the upper part of the lithological sequence. Harker's variation diagram shows the dominance of $\mathrm{SiO}_{2}$ against various oxides in all studied samples in Figure 6. The concentration of $\mathrm{SiO}_{2}$ in massive diamictite and fine sandstone is moderate to high. The ternary QFL diagram, as shown in Figure 5, verified the composition and provenance of all studied samples, i.e. quartz-rich. The plot of major elements $\mathrm{K}_{2} \mathrm{O}$ vs. $\mathrm{Na}_{2} \mathrm{O}$ as shown in Figure 7 quantifies the richness of quartz in all studied samples indicating that these sediments were derived from quartz-rich provenance. The tectonic discrimination diagram between $\mathrm{K}_{2} \mathrm{O} / \mathrm{Na}_{2} \mathrm{O}$ Vs $\mathrm{SiO}_{2}$ shown in Figure 8 infers the area of a passive margin. CIA values and $\mathrm{SiO}_{2}$ vs. $\left(\mathrm{Al}_{2} \mathrm{O}_{3}+\mathrm{K}_{2} \mathrm{O}+\right.$ $\mathrm{Na}_{2} \mathrm{O}$ ) plots as shown in Figure 2 (b) \& 10 for the RPS Fm. suggests a glacial marine environment of deposition under humid to semi-humid climatic conditions.

\section{CONCLUSION}

The presently studied litho-facies sequence is composed of cryogenic sediments (diamictites) that are well preserved in the Sikkim Lesser Himalaya, NE India. The Rangit Pebble Slate Formation of the Himalayan Gondwana is equivalent to the Talchir Formation in the Peninsular Gondwana (Priya et al., 2019). The facies architecture within the studied area manifests upward fining and deepening trends with increasing thickness of shale and alternate silt-mudstone facies. Overall, the Gondwana sequences of Sikkim Lesser Himalaya (Extra-peninsular India) shows the similarity with Peninsular Indian Gondwana sequences in the pattern of sedimentation, depositional environment, and regional sources. The petrological and geochemical analysis of all studied samples shows close affinities with other peninsular Gondwana basins in terms of tectonic setting and provenance, i.e. passive tectonic setting and granitic source. This inference is further confirmed by different discrimination diagrams and/or plots of provenance and tectonic setting. In the Lesser Himalayan sequences of Kashmir, Himachal Pradesh, Arunachal Pradesh and Sikkim, Gondwana sedimentary deposits also have identical depositional environmental conditions (Raichaudhari, 2002; Rashid and Ganai, 2015; Priya et al., 2019; Mahanta et al., 2020). The combined results of both petrography and geochemistry (major oxides) indicates the felsic source might be derived from high-grade metamorphic rocks and plutonic igneous rock. The Chhtonagpur Granite Gneiss Complex (CGGC) and Shillong Plateau Gneissic Complex of the Indian shield lying to the southwest and east of Sikkim-Darjeeling Gondwana basin are composed of high grade migmatitic gneiss, khondalite, 
quartzite, and basic igneous rock (Mukherjee et al., 2019). The massive diamictite and sandstone of Rangit Pebble Slate Formation may have been derived from the Precambrian shields of Chhotanagpur or Proterozoic Himalayan granite, Shillong Plateau Gneissic Complex and quartzose sedimentary rocks which are virtually adjacent to the Rangit basement. The diamictite facies, dropstones, marine fossils and CIA values clearly indicate a glacial environment of deposition, while the upper sequences may be consequences of marine transgression. This study particularly helps to join the dots in the lines of the paleogeographic map of late Paleozoic glaciations and paleo-Tethys realm during the Permo-Carboniferous period in Gondwanaland.

\section{ACKNOWLEDGEMENT}

The authors are thankful to the Head of Department, Sikkim University for his constant support and provision of infrastructural facilities. We are also sincerely thankful to the Director of Birbal Sahni Institute of Palaeosciences, Lucknow, India for providing geochemical laboratory facilities. The authors also thank Dr. Nischal Wanjari for his advice and constructive suggestions for improving an earlier draft of this manuscript. We would also like to acknowledge the Forest department, Govt. of Sikkim for their permission to carry out the fieldwork in South Sikkim. R.K. Priya is grateful to Sikkim University for providing him with a Research Fellowship.

\section{ORCID}

Raj Kumar Priya (D) https://orcid.org/0000-0003-0918-8663 Vinod Chandra Tewari (D) https://orcid.org/0000-0003-3392-1298 Rakesh Kumar Ranjan (D) https://orcid.org/0000-0001-8745-3923

\section{REFERENCES}

Acharyya, S.K. (1971). Rangit Pebble-Slate A New Formation from Darjeeling Foothills. Indian Minerals, Geological Survey of India, 25(1), 6064.
Acharyya, S.K., Ray, K.K. (1977). Geology of the Darjeeling-Sikkim Himalaya, guide to excursion No.4. $4^{\text {th }}$ International Gondwana Symposium, India. $23 \mathrm{pp}$.

Aristizabal, E., Roser, B. \& Yokota, S. 2005. Tropical chemical weathering of hillslope deposits and bedrock source in the Aburra' Valley, northern Colombian Andes. Engineering Geology, 81, 389-406.

Bhatia M.R. (1983). Plate tectonics and geochemical composition of sandstones. The Journal of Geology, 91(6), 611-627.

Bhatia M.R. \& Crook K.A.W. (1986). Trace element characteristics of graywackes and tectonic setting discrimination of sedimentary basins. Contributions to Mineralogy and Petrology, 92, 181-193. https://doi.org/10.1007/BF00375292

Chakraborty, S., Anczkiewicz, R., Gaidies, F., Rubatto, D., Sorcar, N., Faak, K., Mukhopadhyay, D.K., Dasgupta, S. (2016). A review of thermal history and timescales of tectonometamorphic processes in Sikkim Himalaya (NE India) and implications for rates of metamorphic processes. Journal of Metamorphic Geology 34, 785-803. https://doi.org/10.1111/jmg.12200

Condie, K.C., Marais, D.J.D., Abbott, D. (2001). Precambrian superplumes and supercontinents: a record in black shales, carbon isotopes and paleoclimates. Precambrian Research, 106(3-4), 239-260. https://doi.org/10.1016/S0301-9268(00)00097-8

Crook, K.A.W. (1974). Lithogenesis and geotectonics: the significance of compositional variations in flyscharenites (graywackes), In: R.H. Dott, \& R.H. Shaver, (Eds.), Modern and ancient geosynclinal sedimentation ( $\mathrm{pp} 304-$ 310). SEPM Special Publication, V.:1 https://doi.org/10.2110/pec.74.19.0304

Dabard, M.P. (1990). Lower Brioverian formations (Upper Proterozoic) of the Armorican Massif (France): Geodynamic evolution of source areas revealed by sandstone petrography and geochemistry.Sedimentary Geology69(1-2),45-58. https://doi.org/10.1016/0037-0738(90)90100-8

Dickinson, W.R. \& Suczek, C.A. 1979: Plate tectonics and sandstone compositions. The American Association of Petroleum Geologists Bulletin, 63(12), 2164-2182. https://doi.org/10.1306/2F9188FB-16CE-11D7$8645000102 \mathrm{C} 1865 \mathrm{D}$ 
Dickinson, W.R., Beard L.S., Brakenridge, G.R., Erjavec, J.L., Ferguson, R.C., Inman, K.F., Knepp, R.A., Lindberg, F.A. \& Ryberg, P.T. (1983). Provenance of North American Phanerozoic sandstones in relation to tectonic setting. GSA Bulletin, 94(2), 222-235. https://doi.org/10.1130/0016-7606(1983)94<222: PONAPS $>2.0 . \mathrm{CO} ; 2$

Dobrzinski, N., Bahlburg, H., Strauss, H. \& Zhang, Q.R. (2004). Geochemical climate proxies applied to the Neoproterozoic glacial succession on the Yangtze Platform, South China. In: G. Jenkins, M. McMenamin, C.P. McKay \& L. Sohl (Eds), The Extreme Proterozoic: Geology, Geochemistry and Climate (pp. 13-32). American Geophysical Union Monograph Series, 146.

Geological Survey of India (GSI), (2012). Geology and mineral resources of the state of India. (Miscellaneous Publication No.30, Part-19), Sikkim, 19-21.

Gupta, S.S \& Roy, S.S. (1981). Pebble-Slates in parts of eastern Himalaya-evidence for Pre-Gondwana deformation in Himalayan rocks. Journal Geological Society of India, 122, 346-350.

Kahmann, J. A., Seaman, J. III \& Driese, S.G. (2008). Evaluating trace elements as paleoclimate indicators: multivariate statistical analysis of Late Mississippian Pennington Formation paleosols, Kentucky, U.S.A. Journal of Geology, 116(3) 254-268.

Mahanta, Bashab N., Syngai, B.R., Sarmah, R.K. Goswami, T. K. \& Kumar, A. (2020). Geochemical signatures of Lower Gondwana sandstones of eastern Arunachal Himalayas, India: Implications for tectonic setting, provenance and degree of weathering. Russian Journal of Earth Sciences, 20 (2), Article ES2003. https://doi.org/10.2205/2020ES000698

McLennan, S.M., Hemming S., McDaniel, D.K. \& Hanson, G.N. (1993). Geochemical approaches to sedimentation, provenance, and tectonics. In: M.J. Johnsson \& A. Basu (Eds.), Processes controlling the composition of clastic sediments (21-40). Geological Society of America, Spec. Paper, 284. https://doi.org/10.1130/SPE284-p21

Mukherjee, S., Dey, A., Snyal, S. \& Sengupta, P. (2019). Proterozoic Crustal Evolution of the Chotanagpur Granite Gneissic Complex, Jharkhand-Bihar-West Bengal, India: Current Status and Future Prospect. In: S. Mukherjee (Ed), Tectonics and Structural Geology: Indian Context. Springer Geology.

Nesbitt, H.W. \& Young, G.M. (1982). Early Proterozoic climates and plate motions inferred from major element chemistry of lutites. Nature 299, 715-717.
Priya, R.K., Tewari V.C.\& Ranjan, R.K. (2019): Permian Tethyan transgression in SikkimDarjeeling Himalaya with special reference to the Paleoclimatic event. Bulletin of Nepal Geological Society, (36), 233-240.

Raichaudhri, A.K, (2002). Study of marine megainvertebrates of the Permian rocks of DarjeelingSikkim Himalaya. Rec., Geol. Surv. India, E.R, 133(3), 25-26.

Rashid, S.A. \& Ganai, J.A. (2015). Preservation of glacial and interglacial phases in Tethys Himalaya: evidence from geochemistry and petrography of Permo-Carboniferous sandstones from the Spiti region, Himachal Pradesh, India. Arabian Journal of Geosciences, 8, 9345-9363. https://doi.org/10.1007/s12517-015-1877-5

Ray, S.K. \& Neogi, S. (2011). Extent and analogues of the Rangit window in the Sikkim Himalaya. Indian Journal of Geosciences 65 (4), 275-286.

Roser, B.P. \& Korsch, R.J. 1986: Determination of tectonic setting of sandstone-mudstone suites using $\mathrm{SiO}_{2}$ content and $\mathrm{K}_{2} \mathrm{O} / \mathrm{Na}_{2} \mathrm{O}$ ratio. The Journal of Geology 94(5), 635-650. https://doi.org/10.1086/629071

Roy, S.S. (1973). Gondwana Pebble Slate in the Rangit valley tectonic window, Darjeeling Himalayas and its significance. Journal of Geological Society of India, 14(1), 31-39.

Scheffler, K., Hoernes, S. \& Schwark, L. (2003). Global changes during carboniferousPermian glaciation of Gondwana: linking polar and equatorial climate evolution by geochemical proxies. Geology, 31(7), 605-608. https://doi.org/10.1130/0091-7613(2003)031 $<0605$ :GCDCGO>2.0.CO;2

Suttner, L.J. \& Dutta, P.K. (1986). Alluvial sandstone composition and paleoclimate; I Framework mineralogy. Journal of Sedimentary Research 56(3), 329-345. https://doi.org/10.1306/212F8909-2B24-11D78648000102C1865D

Takahashi, G. (2015). Sample preparation for X-ray fluorescence analysis III. Pressed and loose powder methods. Rigaku Journal, 31(1), 26-30.

Tewari, V.C. (2011). Stromatolites, organic walled microorganisms, Laser Raman Spectroscopy and Confocal Laser Scanning Microscopy of the Meso-Neoproterozoic Buxa Formation, Ranjit Window, Sikkim Lesser Himalaya, NE India. In: V.C. Tewari \& J. Seckbach (Eds.), Stromatolites: Interaction of Microbes with Sediments, Cellular Origin, Life in Extreme Habitats and Astrobiology, 18 (pp. 495- 524), Springer Science Business B.V. 2011. 